Vadym Aleksandrov,

Ph.D., Associate Professor, Sumy State University, Ukraine

DRCID ID, 0000-0001-5213-1676

email: v.alexandrov@finance.sumdu.edu.ua

Pavlo Rubanov,

Dr.Sc., Associate Professor, Sumy State University, Ukraine

(iD) ORCID ID, 0000-0002-9415-8786

email: p.rubanov@finance.sumdu.edu.ua

Madi Mazhed Eisa,

Ph.D., Member of the European Association of Urology, Germany

Correspondence author: v.alexandrov@finance.sumdu.edu.ua

\title{
PROBLEMS OF IMPLEMENTATION OF COMPULSORY HEALTH INSURANCE IN UKRAINE
}

Abstract. This article summarizes the arguments and counterarguments within the scientific discussion on health care financing by introducing compulsory health insurance in Ukraine and improving voluntary one. The study's primary purpose is to theorize and determine the main directions and recommendations for implementing compulsory health insurance in Ukraine. Systematization of scientific background concerning the study problem showed that Ukrainian national and municipal health care institutions didn't provide free medical care in the amount and quality guaranteed by the Constitution of Ukraine. Therefore, the relevance of solving this scientific issue is the necessity of comprehensive health care reforming (especially funding) considering compulsory health insurance. To achieve this goal, the study was conducted in the following logical sequence: analyzing models, historical experience, and a hybrid budget insurance system of health care financing; identifying the Ukrainian health insurance features during the pandemic in 2020; clarifying the problems of health insurance development in Ukraine and the world; analyzing and considering the theoretical base on solving health insurance issues; retrospective analysis of the three-level insurance model; developing the practical recommendations for improving the mechanisms of compulsory health insurance implementation. The methodological tools of the study were the methods of dialectical scientific knowledge, systematic approach, statistical and comparative analysis, a review of scientific background, regulatory framework, and insurance companies' reports. The study involves data for 2002-2021. The object of the study is the health insurance system and state mechanisms for regulating compulsory and voluntary health insurance in Ukraine. The obtained results showed that the introduction of compulsory health insurance in Ukraine addressed the expanding availability of medical services to the general population and attracting additional resources in health care. The study empirically confirms and theoretically proves that the Ukrainian government should determine the main health services provided and the insurance premium amount, coordinate the interaction between insurance parties, resolve conflict situations, provide the legal basis for the system functioning, control financial flows and activity insurance fund. The study results can be helpful for insurance market professionals, financiers, and economists in the health care industry, researchers, and students of economic specialties.

Keywords: insurance medicine, compulsory health insurance, voluntary health insurance, insurance funds, health insurance models, financing, health care.

Introduction. Insurance medicine guarantees a citizen the particular medical services delivery for free in the insured event's occurrence (deterioration of health). However, there should be a contract with an insurance organization (insurer) to involve a medical institution to provide quality medical services. It is worth noting that the insurer is responsible for medical care (risk) payments since the first citizen's payment to the relevant fund.

Cite as: Aleksandrov, V., Rubanov, P., \& Mazhed Eisa, M. (2021). Problems of Implementation of Compulsory Health Insurance in Ukraine. Health Economics and Management Review, 1, 76-88. http://doi.org/10.21272/hem.2021.1-08

76 
For analyzing the modern financial mechanism in Ukrainian health care, in general, and health insurance, it is essential to consider Article 49 of the Constitution of Ukraine. It ensures civil rights on health care, medical care, and health insurance. Therefore, the government has to provide effective and accessible medical care for all citizens. Moreover, it is a task to encourage the development of medical institutions of all forms of ownership.

Despite the mentioned above, the country's deteriorating financial and economic situation reduces the government's capacity to meet the public needs in health care at the expense of budget funds. Because of this, the legislative regulation of the introduction of compulsory state health insurance is an urgent and important task.

This study aims at theoretical justification and determining the main directions and recommendations for introducing compulsory health insurance in Ukraine and possible ways to improve insurance medicine in general.

Literature Review. Many domestic and foreign scientists significantly contributed to the investigation of health insurance. It is appropriate to indicate such scientists as Avramenko N., Bazylevych V., Yuriy S., Shavarina M., Shamanska N., Plisa V., Shumeldi Ya., Keynes J., Stigler J., Gel-Breit J., Meyer K, and others. Notably, in the study (Bauernschuster et al., 2020), the researchers investigated the consequences of for the first time introduced the national health insurance system by Bismarck in December 1984. Based on recently digitized panel data on mortality in Prussia, the authors argued that the implemented insurance system played an important role in the sharp decline in mortality before 1900 (1.91 cases per 1000 workers). The findings showed that compulsory health insurance provided a one-third reduction of mortality among low-income households. In turn, the study (Card et al., 2008) indicated that expanding the health insurance for the 65+ age group in the United States under more effective medicaments and treatments reduced mortality by 2-4 percent within a year.

Mestres, Casasnovas and Castelló (2021) analyzed the consequences of imposing restrictions on public health care for illegal migrants by Spain in 2002. Thus, the scientists proved the health insurance impact on mortality level. They stated that the monthly mortality rate increased by 0.31 per 100000 people during 4 years since the government denied access to the state health program for irregular migrants. Besides, that might indirectly affect the citizens due to the risk of infectious disease growth.

Ivanchuk (2019) investigated voluntary health insurance as a source of financial support for health care. The scientist considered voluntary health insurance in the European countries and analyzed voluntary health insurance as an element of health care financing under market conditions. Therefore, the study findings identified the benefits of voluntary health insurance, including the mobilization of extra funds in health care, expanding consumers' choices in health services, promoting innovation. On the other hand, this study provided the emerging risks to ensure equitable funding, access to services, and efficiency in resource allocation. Kozhemyachenko and Malkina (2020) analyzed the scope of health insurance services and the systematicity in Ukrainian health insurance practices. The obtained results described the current state and development level of relations between the principal element of the health insurance system.

The study Lisovskaya (2019) presents a short-term forecast of the volume of net insurance premiums using mathematical expectations. The author analyzed the dynamics of the key indicators of voluntary health insurance in the Ukrainian market of medical insurance services. The scientist Shupa (2018) conducted compared the health insurance systems in Ukraine and Estonia. Therefore, the obtained results showed that compulsory health insurance effectiveness depended on the country's concept of insurance medicine. However, in most cases, it turns out to need to be reformed and improved. The author also highlighted the positive and negative tendencies of compulsory health insurance and the advantages and disadvantages of the Estonian health insurance system, which is cost-attractive for the population but does not provide quick access to health services. 
The systematization of scientific background indicated the gaps in the investigation of Ukrainian compulsory health insurance. Thus, it is appropriate to determine the most optimal structure of the health insurance system in Ukraine, the ratio of compulsory and voluntary insurance, etc. Besides, there is a need to analyze the draft laws in health insurance financing for the last 18 years and its current version, which could be adopted.

Methodology and research methods. The study involved several general scientific methods as follows: the method of theoretical comparison (regarding comparative characteristics of health insurance models in different countries), generalization method, grouping (to determine the characteristics of the most effective and financially sustainable social health insurance systems), analysis and systematization (concerning the implementation of social health insurance in Ukraine and defining tasks for reforming the insurance system in Ukraine).

Results. Health insurance is one of the key components of the national health care system in social and economic terms. It stands to define health insurance as a social protection form in health care that aims to protect against risks that threaten human health and life. In turn, health insurance guarantees medical care under any circumstances related to illness or safety incidents (On compulsory, 2016).

Nowadays, the implementation of compulsory state health insurance is the main point in Ukrainian medical reforms. In turn, compulsory state health insurance is considered to be an effective and efficient way to cover costs on treatment, diagnosis, prevention, rehabilitation of illnesses, or safety incidents.

It stands to note the introduction of compulsory state health insurance is outlined as follows:

- under terms of compulsory state health insurance, funds are accumulated for public medical supplies by the target insurance premiums expense;

- legal relations between all participants (insurers, insured, health care institutions, etc.) are regulated on a contract basis;

- health insurance implementation would promote competition between health care institutions and insurance companies;

- health care facilities would provide medical care with accumulated funds at the expense of funds accumulated in the compulsory state health insurance system.

There are more than roughly a dozen prepared alternative bills defining the legal basis for health insurance. However, the introduction of health insurance should be immediate and solve different problems (Chornomaz, 2015).

Medical insurance is the social protection of the population regarding personal health when collective liability is organized (financial and medical assistance) in insurance cases. The findings showed that collective or solidarity assistance mechanisms were developed and implemented in various countries worldwide for a long time. People used the methods of mutual collective insurance, creating insurance funds to pay them the required amount of funds to cover the cost of treatment. Such insurance mechanisms initially operated without a tariff system, i.e., were non-profit. Because of this, there was no commercial interest in insurance companies (Bilyk and Kachmarchyk, 2013).

Based on mentioned above, the main tasks of compulsory health insurance are as follows:

- $\quad$ equal rights for citizens to receive free medical care to maintain public health;

- $\quad$ adequate financial support for delivering medical services and assistance to the population;

- creation and implementing a competitive market (using the up-to-date medical equipment) of medical care and care delivery.

The state mechanisms for reforming medicine in Ukraine have provoked intense scientific and practical discussions about its reasonableness and optimal directions.

It stands to mention that large state-controlled joint-stock insurance companies serve the current Ukrainian health insurance market. However, they are not interested in serving solvent citizens (most 
Ukrainians) with significant insurance risks. In turn, it limits access to health insurance and formulates distrust of health care reforms.

Nowadays, health insurance includes the following elements such as:

- government and state subsidies;

- insured people (patients, employees) and their contributions;

- employers (state and commercial enterprises and institutions) and their target contributions;

- insurance fund with the accumulated funds to pay for the treatment of insured persons;

- medical institutions with their package of medical services;

- pharmacies that provide medical institutions and patients with drugs, necessary drugs, and equipment.

In the 1920s, there was proposed the government doctrine in health care, which guaranteed free medical services. Further, commercial (private) health care systems were created based on state licenses. These systems required payment for the medical service provided. Notably, both mentioned above systems existing as in Ukraine, so in most countries.

In Germany, insurance medicine (or health insurance) originated in the nineteenth century. It is worth mentioning that there were no government interventions in the insurance process (a mechanism). The trade unions' creation at large enterprises contributed to establishing «Medical Funds» - «Bismarck» on behalf of Chancellor Otto von Bismarck (Bauernschuster et al., 2020). They became the basis of collective and solidarity insurance in providing quality medical services. At the same time, Germany, Austria, Belgium, Hungary, France, the Netherlands, and other countries implemented and developed similar medical systems with dual government and insurance funding (Drobot, 2015).

In Ukraine, the first attempts to develop compulsory health insurance as a state mechanism and doctrine of new medicine were in 2002. Over the last few years, there were proposed various ideas regarding the implementation of health insurance, insurance fund, and health care reforms such as:

- developing a new regulatory framework;

- $\quad$ revising several laws and codes;

- $\quad$ creating the concept of insurance fund (or medical insurance fund);

- $\quad$ maintaining the insurance fund by contributions of individuals and legal entities, the government of funds social insurance and temporary disability;

_ $\quad$ involving or not the private insurance companies in insurance medicine;

- $\quad$ applying voluntary insurance practices to the Ukrainian realities;

- $\quad$ using foreign experience.

It stands to note that the new draft law «On Compulsory Health Insurance» covers the ideas and issues mentioned above. In turn, the main problem of financing health care is the lack of budget funds. There is a necessity to maintain the health care system at an acceptable level in cutbacks to budget funding or adjust the additional income flow from medical activities. Notably, the healthcare industry system by N. Semashko is an inefficient model of the Soviet period. Thus, it should be replaced by more progressive models. However, for a long time, Ukraine has denied the insurance nature of the current system. In turn, there were myths about the inefficiency of the insurance system of medical financing, even though demographic, social, and medical indicators were competitive.

The compulsory health insurance theory (CMI) extrapolates the possibility of an unexpected accident in life, which will call for high costs. Therefore, for compensating losses caused by various accidental circumstances, it is necessary to have a special source of resources. It is historically proven that only insurance (reserve) funds can be the source mentioned above. Besides, there are three methods of developing insurance funds as below. 
The first method to form insurance funds is self-insurance. Thus, people reserve money for emergencies or illnesses. In this case, the individual funds were combined into family, clan, and community ones. Indeed, nowadays, it is the most common way of insurance fund generation.

The second method is a centralized insurance fund generation at the country level. The government mobilizes budget funds to solve existing or future emergencies. Nowadays, many developed countries consider this method as an intensive and effective social system. For instance, on 28 December 2014, the «Social Insurance Fund» was merged out of extra-budgetary insurance funds, such as the Social Insurance Fund for Temporary Disability (established in 2001) and the Social Insurance Fund for Accidents at Work (established in 1999) (Compulsory, 2013). Notably, the joint fund started work in November 2017 after a transition period. Besides, the examples of targeted centralized insurance funds were the Social Insurance Fund for Accidents at Work and Occupational Diseases (established in 1999) and the Pension Fund of Ukraine (established in 1990). Even though the citizens' insurance premiums support these funds, they are compulsory and found by the government. It stands to mention that the Ukrainian government budget covers the deficit of these funds.

Furthermore, some budget items of different levels perform insurance functions. For example, the State Emergency Service of Ukraine budget functions as an insurance fund since it is formed based on estimates of possible losses from industrial and natural disasters (insured events). Another example is the country's defense budget formed by estimating the required combat performance in peacetime, the forecast of local conflicts probability, warfighting, etc.

Finally, the third method of developing insurance funds is the efforts of insurance companies. The features of this method are as follows:

- establishing the insurance funds through insurance premiums, i.e., the concentration of funds raised occurs within insurance companies;

- using actuarial expectation to determine the amount of insurance premium;

- only insured persons could apply for insurance payment in case of emergency.

The insurance funds take place in social and commercial insurance. In turn, social insurance covers the principle of collective solidarity to protect insured persons from social risks. On the other hand, commercial insurance follows the principle of individuality, i.e., insurance based on the conclusion of an individual contract of voluntary or compulsory insurance. Generally, commercial insurance is used if social insurance does not work or to expand insurance protection. Besides, the main differences between commercial and social insurance are the purpose (profit-earning); methods of determining risks and the number of insured persons (concluded contract); direct dependence the insurance premiums amount on tariffs and insurance payout amount; subjects of management of the insurance funds (insurance companies).

Therefore, health insurance is a type of personal insurance provided in the social sphere as commercial insurance on a mandatory and voluntary basis. Notably, there are three main types of financial models in health care worldwide such as:

1) budget-insurance model - the contributions of employers, employees, and budget funds raise the insurance fund. That is the most common model, especially in Germany, Switzerland, etc;

2) budget model - the insurance fund is created at the expense of budgetary funds (Great Britain, Finland, etc.);

3) entrepreneurial (market) model - the insurance fund is maintained by contributions of voluntary health insurance (USA) (Sharypov, n.d.).

It is essential to note that all systems are periodically reformed.

The basic financial characteristics of the budget-insurance model are: 
- availability of several funding sources (multi-flow) due to the combination of budgetary approaches and the insurance principle in creating health funds (employers' taxation and payments for the unemployed);

- determining tariffs for medical services based on a limited set of articles defining the cost of the medical services;

- medical care pay considering different medical organizations activities in the medical services delivery;

- contractual arrangements determining the procedure for financing medical organizations by insurance companies;

- planning medical care based on the established volume and financial specifications.

The financial mechanism of local self-government has a complex structure. It can be represented as a set of four elements as follows:

- medical care planning mechanism;

- the mechanism of financial provision of compulsory health insurance;

- the mechanism of financial distribution between the participants of the compulsory health insurance;

- financial control mechanism (On Insurance, 1996).

Insured people receive medical care based on contractual relations between the participants of the compulsory health insurance system. The insurance health company and the medical institution constitute an agreement on the provision and payment of medical care by compulsory health insurance. Under this agreement, the medical organization is obliged to provide medical care to the insured person within the compulsory health insurance program. On the other hand, the insurance institution undertakes to pay for medical care.

Indeed, insurance companies have a special place in the compulsory health insurance system. Thus, they directly communicate with insured people who need medical care. Herewith, the insurance organization has to separate the target income and own funds.

The main financial controlling body of compulsory health insurance is the insurance fund. It concerns the volume, terms, quality, and conditions of medical care.

Nowadays, only 54 countries have introduced health insurance and guarantee universal medical coverage. Besides, in these countries, health care systems have a mixed structure of funding organization which consists of 3 main models as follows:

- - budget model, with basic public funding and joint taxation (common in 22 countries such as UK, Australia, Canada, etc.);

- - social health insurance model, financed by compulsory joint contributions of the government, employers, and employees (common in 30 countries such as Germany, France, Japan, Korea, etc.);

- - private health insurance model is funded by voluntary contributions from employers or employees (common in the US and Singapore) (Drobot, 2015).

Table 1 presents the comparative analysis of different health insurance models by country.

It is essential to highlight that the competition for healthy and solvent patients is one of the health insurance problems. Besides, elderly people with serious illnesses, pregnant women, and young children keep out of the spotlight because of the high insured events potential. In such cases, they might lose access to the necessary medical care due to the denial of insurance coverage or the high cost of medical services. 
Table 1. Comparative analysis of different health insurance models

\begin{tabular}{|c|c|c|c|}
\hline Model type & Form of financing & Advantages & Disadvantages \\
\hline $\begin{array}{l}\text { Bismarck (budget } \\
\text { insurance) } \\
\text { (Germany) }\end{array}$ & $\begin{array}{l}\text { - centralized state fund; } \\
\text { - a certain percentage of } \\
\text { wages; } \\
\text { - formation of an insurance } \\
\text { fund for both individuals } \\
\text { and legal entities }\end{array}$ & $\begin{array}{l}\text { - high degree of protection; } \\
\text { - ensuring social stability; } \\
\text { - financial openness of the } \\
\text { model }\end{array}$ & $\begin{array}{l}\text { - lack of resources in the } \\
\text { system } \\
\text { health care and pharmacy; } \\
\text { - insufficient quality of } \\
\text { medical and pharmaceutical } \\
\text { services; } \\
\text { - administrative command } \\
\text { management }\end{array}$ \\
\hline $\begin{array}{l}\text { Beverage (state, budget) } \\
\text { (Great Britain) }\end{array}$ & $\begin{array}{l}\text { - financing from the state } \\
\text { budget on a residual basis }\end{array}$ & $\begin{array}{l}\text { - high degree of protection; } \\
\text { - ensuring social stability }\end{array}$ & $\begin{array}{l}\text { - shortage of resources in } \\
\text { the health care and } \\
\text { pharmacy system; } \\
\text { - insufficient quality of } \\
\text { medical and pharmaceutical } \\
\text { services; } \\
\text { - administrative command } \\
\text { management }\end{array}$ \\
\hline $\begin{array}{l}\text { Private model of health } \\
\text { insurance } \\
\text { (USA) }\end{array}$ & $\begin{array}{l}\text { - centralized form at the } \\
\text { expense of payments of } \\
\text { policyholders; } \\
\text { • independent participation } \\
\text { of the state }\end{array}$ & $\begin{array}{l}\text { - high degree of protection; } \\
\text { - ensuring social stability }\end{array}$ & $\begin{array}{l}\text { - high cost of insurance } \\
\text { rates; } \\
\text { - social tension in society }\end{array}$ \\
\hline
\end{tabular}

Sources: developed by the authors.

For removing the above inequality, the World Health Organization recommends creating joint funds. For example, such funds operate in many countries with social health insurance, such as Korea, Hungary, Japan, etc. Besides, the schemes of gradual fund amalgamation (Baltic countries) or using risk equalizer mechanism (Germany, France, Belgium, etc.). Notably, Germany combines more than 130 funds to accumulate financial resources to cover insurance risks. If necessary, this reserve could be raised by government budget funds. Then, the collected money is adjusted considering the correction factors such as sex, age, income level, and health status to further redistribution between insurance funds.

Tariff policy bases on economic tariff realism and balances with the general income base. Generally, it assures the depreciation of fixed assets. Moreover, the common practice is to set tariffs based on negotiations with insurance funds or their associations providing medical services.

The practice of ordering medical services in social health insurance countries is as follows:

- the benefits package includes comprehensive lists of services;

- methods of payment combine approaches to payment for a particular service (tariffing, clinical cost groups, etc.), considering the medical care results and quality.

The international experience analysis findings showed that the most effective and financially sustainable social health insurance systems are the following models:

- the amount of health care financing is not less than 5\% of GDP;

- high self-regulation level of social health insurance systems, while all social partners are involved in management;

- funding is provided jointly by the government, employers, and employees;

- joint accumulation of funds;

- providing the realistic and balanced tariff policy by negotiation and considering depreciation costs;

- using services payment methods focused on performance. 
The mentioned above indicates that the developed countries attract and implement insurance medicine for additional funding of the healthcare industry. Therefore, for Ukraine, it is essential to learn the best international experiences in introducing compulsory social health insurance. Notably, the current stage of state social reforms is characterized by intensive changes in legislation, the search for optimal structures and criteria for functioning, the emergence of new departmental functions and adjustment of existing ones, changes in the list of services provided to the population.

Compulsory health insurance is essential in the current system of relations between the government and citizens. Compulsory health insurance implementation is an integral part of state social insurance. It would provide the entire population of Ukraine with additional financial resources to treat many diseases on the principles of collective solidarity, as in insurance cases. It stands to mention that principles of collective solidarity require the introduction of the following components into the insurance system:

- contributing participant of insurance payments;

- $\quad$ insurance fund;

- $\quad$ state and market mechanisms of introduction, functioning, development, and management of compulsory medical insurance.

Recently, Ukraine attempted to introduce compulsory health insurance at different levels of governance (president, government, and Verkhovna Rada of Ukraine). Compulsory health insurance would be a harmonic component of social insurance under the appropriate combination of compulsory and voluntary insurance, considering the best practices of the Ukrainian and international insurance markets. In this case, all government branches were introducing bills on developing compulsory insurance. During 19 years in Ukraine, there were eighteen attempts to adopt a law on compulsory health insurance in Ukraine. In 2021, the Verkhovna Rada of Ukraine considers another bill introduced on 12.05 .2020 under No. 3464 (On financial, 2020).

A detailed review of this bill (On financial, 2020) indicated the need for its improvement, especially the purpose and functioning of the insurance fund in Articles 15 and 18. It is worth emphasizing that these articles do not detail the main fund provisions. Besides, the «Insurance Fund» is still the most complicated object of health insurance. Therefore, there are a lot of discussions among experts and legislators concerning the basic issues of the insurance fund considering different issues such as:

- $\quad$ sources of raising funds;

- $\quad$ principles and main characteristics of the fund functioning;

- financial strategy, management regulations, and restrictions on the accumulated funds;

- $\quad$ fund ownership form (public or private);

- $\quad$ status of the entity managing the fund and the management regime (government or market management, a mixed form);

- $\quad$ management structure and governing bodies powers;

- $\quad$ sources and volumes for cover fund administrative and operational expenses;

- $\quad$ regulations on the income distribution, in particular, the banks' funds deposit income;

- $\quad$ security issues regarding the accumulation, storage, and use of the fund;

- guarantee mechanism for the fund contributing participants and financing sources;

- inheritance mechanism;

- $\quad$ transfer procedure of fund share ownership in the liquidation of these enterprises, bankruptcy, restructuring, etc.

It stands to highlight that the activities of the «Authorized official of compulsory health insurance» are undeveloped completely in the presented draft law in Art. 21 (On financial, 2020). 
Because of the above, it can be stated that attempts to introduce compulsory health insurance have not to effect even at the legislative stage. Besides, this process is further complicated by significant differences in healthcare reform concepts and health insurance among law-makers and academics.

The vast majority of scientists believe that Ukraine needs urgent social insurance reforming to introduce state compulsory health insurance. In turn, the social insurance reform would allow most medical institutions to earn money, i.e., work on full self-financing, except for a limited list of medical institutions are funded by the government budget (Family Code of Ukraine, 2002).

On the other hand, some scientists indicate the appropriate to gradually introduce insurance medicine with the active involvement of extra-budgetary funds, revenues from using the statutory list of paid services, funds from renting fixed assets, non-core activities, charitable contributions, etc. Notably, this approach essentially means transitioning to a budget-insurance form of medical financing (Zhyrii, 2020). Thus, it stipulates the share of public funds should be at least 60 percent of the total funding.

The findings show that the Ukrainian medical insurance models are the most similar to Netherlands and Israel. In this case, the government and citizens are equally responsible for financing public health measures. Therefore, the government assumes funding for the benefits package, covering the most socially important areas, such as emergency, psychiatric, and tuberculosis care, infectious diseases, heart attacks, strokes, and oncology. Notably, in 2021, the oncology package in Ukraine would cost 84 thousand UAH (5UA, 2020). This approach assumes that a person pays for other medical services that are not included in the specified basic package. For example, this applies to dental prosthetics, routine non-lifethreatening surgeries, additional examinations, or more comfortable hospital conditions. Thus, the patients could pay for these additional services through voluntary or additional insurance.

Nowadays, the introduction of insurance medicine in Ukraine faces two problems. The first is the lack of a ready-to-implement legal framework. The second problem is the prosperous shadow economy avoiding wage taxes. As a result, it complicates the legalization of income and the payment of insurance premiums. Thus, introducing the insurance medicine system is possible if the amount of shadow salaries is reduced by more than $70 \%$ (5UA, 2020).

The introduction of health insurance could solve several national strategic problems. Moreover, it would improve the health of the nation. However, for introducing social health insurance in Ukraine, it is necessary to solve several current problems as follows:

- lack of state guarantees for insured persons;

- lack of compulsory health insurance;

- lack of budget financing system;

- functioning health care without reforms since the 1990s;

- medical institutions and related organizations fail to fulfill funding and work organization requirements for the medical treatment Ukraine;

- corruption and shadow wages, low tax culture causing low GDP growth;

- the lowest healthy living rate in Europe requiring medical services;

- the lowest health care spending in Europe.

The statistical data showed that expenditures on medicine in European countries are higher by 2 times (6-12\% of GDP) than in Ukraine. Moreover, in 2019, Ukraine was ranked last in healthy living rate (61.7 years) among all European countries (the highest European level was 71.9 years) (Sharypov, n.d.). Herewith, the Human Development Index of Ukraine has not improved over the last 10 years.

Therefore, even though Ukraine lags far behind European countries in social protection, it is vital to develop compulsory social health insurance as the main state mechanism for raising social standards.

Notably, the high price policy of voluntary health insurance and its conditions make it available only to corporate clients. Thus, the population minority has the opportunity to purchase this certificate of 
insurance. Ukraine's insurance market development is prolonged and unsystematic. The share of health insurance is too small since the lack of public demand. Besides, the insurance companies lose interest in health insurance due to its high cost. As a result, it leads to reducing funding for this type of insurance.

The coronavirus pandemic increases the urgency of this problem. Therefore, it requires effective strategies for government regulation and developing voluntary and compulsory health insurance. In this case, there are several public administration areas for health insurance financing as follows:

- $\quad$ granting the right to a tax preference (under certain restrictions) for insureds - individuals in voluntary health insurance;

- $\quad$ introduction of moderate interest rates on salary accounting, which would stimulate the getting certificate of compulsory health insurance;

- $\quad$ simplifying the insurance payments registration;

- $\quad$ an effective insurance rate setting.

The findings showed that legislators have submitted to the Verkhovna Rada of Ukraine eighteen draft regulations over the past nineteen years. These bills provided the immediate introduction of compulsory health insurance with self-financing mechanisms by leading medical institutions when providing a standard (social) set of medical services. Besides, they covered many general provisions without reference to medical practice.

It is worth mentioning the suggestion to implement the graded introduction compulsory health insurance scheme. In this case, the government should maintain a significant share of funding (up to $60 \%$ ). The analysis of the above bills showed that the state budget and charitable sources had to develop the insurance funds. However, it is worth considering the compromise approach since the complexity of graduated implementation of state mechanism. Thus, the government should assume government compliance monitoring and guarantee provision with partial funding with its gradual increase.

Health insurance, like other types of social insurance, is provided both compulsorily and voluntarily. The choice between these types of insurance depends on a particular person. The system of compulsory social insurance, especially at the current Ukrainian economic development, provides social protection to citizens providing government guarantees on a certain standard of living.

Comparative analysis of the main differences between compulsory and voluntary forms of insurance showed as follows:

1) the government bodies provide compulsory social insurance, while private insurers - voluntary insurance;

2) the insurers or their associations elaborate on the rules of voluntary insurance, while the government body - compulsory insurance;

3) compulsory social insurance assures a general protection system for the economically active citizens and their dependents from losing income due to illness, unemployment, maternity, death of a breadwinner, disability, old age, in case of voluntary insurance - individual or specified protection system.

Conclusions. The findings indicated the necessity to further research on foreign models of professional insurance. Notably, special attention should be paid to the issues on assessing the effectiveness of the payment to victims of different insurance models.

The obtained results concluded that compulsory national health insurance is the most effective method to protect healthcare workers from occupational diseases, including COVID-19. Thus, it requires a comprehensive study of the optimal insurance premium and the best international practices concerning introducing compulsory health insurance and developing a new draft law on compulsory health insurance. This law should be based on the market economy principles but with direct government involvement.

Health insurance is part of the general insurance system. However, it has certain unique features associated with the specifics of medical activities. The analysis of health insurance practices showed that 
its implementation requires compliance with the sequence and stages. In turn, the insurance system reforming involves the solution of several problems as follows:

a) determining the medical institution status at the legislative level;

b) standardizing medical technologies to develop a basis for assessing the medical care quality;

c) finding the optimal ratio between compulsory and additional medical care;

d) modernize the experience of health insurance funds;

e) considering the positive international practices in health insurance;

f) finalizing the Law of Ukraine «On Insurance» by expanding it with articles on:

- compulsory health insurance;

- $\quad$ rules of compulsory health insurance;

- the status insurer, management structure, financing mechanisms, and procedures for compensation payment to insureds;

- $\quad$ the procedure for insurance payments (premiums) by individuals and legal entities;

- mechanisms of government regulation and supervision of policyholders and those who make insurance contributions;

- $\quad$ procedures and mechanisms for creating an insurance fund of compulsory health insurance, funding tools, storage and management systems, accrual of interest, and methods of interest distribution between insurers and insureds;

- $\quad$ staffing specifications and requirements for qualification and training of the insurer's staff;

- $\quad$ state guarantees to ensure the reliability of the mechanism and procedures for the accumulation, storage, and distribution of financial resources of the compulsory health insurance fund;

- developing the inheritance mechanism for determining the beneficiaries concerning the accumulated financial resources;

- $\quad$ synchronizing the laws and regulations concerning insurance mechanisms with mechanisms of social protection of the Ukrainians.

The analysis of the international practice on non-commercial health insurance proved its contributions to addressing the availability of health services to the general population and attracting additional resources to health care. Nowadays, Ukraine needs to learn the positive international experience in introducing a new medical care system and paid medicine.

Under compulsory health insurance, the government has to determine the main health services provided and the insurance premium amount; coordinate the interaction of all participants in the system; resolve conflict situations; provide the legal basis for the system functioning; control financial flows and activity insurance fund, etc.

Author Contributions: conceptualization, V. A. and P. R.; methodology, P. R.; validation, P. R. and M. M. E.; formal analysis, V. A.; investigation, V. A., P. R. and M. M. E.; writing-original draft preparation, P. R.

Funding: This research received no external funding.

\section{References}

Bauernschuster, S., Driva, A., \& Hornung, E. (2020). Bismarck's health insurance and the mortality decline. Journal of the European Economic Association, 18(5), 2561-2607. [Google Scholar] [CrossRef]

Bilyk, O. I., \& Kachmarchyk, S. A. (2013). Advantages and disadvantages of introducing a compulsory form of health insurance in Ukraine. Bulletin of the National University «Lviv Polytechnic», 767, 270-276. [Google Scholar]

Card, D., Dobkin, C., \& Maestas, N. (2008). The impact of nearly universal insurance coverage on health care utilization: evidence from Medicare. American Economic Review, 98(5), 2242-58. [Google Scholar] [CrossRef] 
Chornomaz, O. B. (2015). Problems and prospects of health insurance development in Ukraine. Retrieved from [Link] Compulsory health insurance: draft law. № 5655. (2004). Retrieved from [Link]

Compulsory state health insurance: draft law. № 11077. (2012). Retrieved [Link]

Compulsory state health insurance: draft law. № 2597-1. (2013). Retrieved [Link]

Compulsory state social health insurance: draft law. № 1040. (2007a). Retrieved from [Link]

Compulsory state social health insurance: draft law. № 1040-1. (2007b). Retrieved [Link]

Compulsory state social health insurance: draft law. № 4505-1. (2004). Retrieved [Link]

Drobot, Ya.V. (2015). Problems of introduction of obligatory medical insurance in Ukraine and measures for their solution. Financial space, 2 (18). [Google Scholar]

Family Code of Ukraine. № 2947-III. (2002). Retrieved from [Link]

Sharypov, O. (n.d.). In 2019, Ukraine had the lowest life expectancy among European countries - a study. Retrieved from [Link] 5UA .(2020). Insurance medicine in Ukraine: what model is being considered and when are they going to be launched. Retrieved from [Link]

Ivanchuk, O. M. (2019). Voluntary health insurance: Foreign experience for Ukraine. Actual Problems of State Administration, 2, 177-182. [Google Scholar]

Kozhemyachenko, O. O., \& Malkina, E.V. (2020). Problems of formation of the health insurance system in Ukraine. Formation of Market Relations in Ukraine, 5 (228), 104-111. Retrieved from [Link]

Lisovskaya, O.O. (2019). Forecasting the main indicators of activity in the market of medical insurance services in Ukraine. Business Inform, 5(496), 117-122. [Google Scholar]

Mestres, A. J., Casasnovas, G. L., \& Castelló, J. V. (2021). The deadly effects of losing health insurance. European Economic Review, 131, 103608. [Google Scholar] [CrossRef]

On compulsory social health insurance: draft law. № 2462a. (2015). Retrieved from [Link]

On compulsory state social health insurance in Ukraine: draft law. № 4981-2. (2016). Retrieved from [Link]

On compulsory state social health insurance: draft law. № 2597 (2013). Retrieved from [Link] [Link]

On financial provision of health care and compulsory health insurance in Ukraine: draft law. № 1178. (2019). Retrieved from

On financial provision of health care and compulsory health insurance in Ukraine: draft law. № 3464. (2020). Retrieved from [Link]

On health care financing and compulsory health insurance in Ukraine: draft law. № 9163. (2018). Retrieved from [Link]

On health care financing and compulsory social health insurance in Ukraine: draft law. № 4744. (2009b). Retrieved from [Link]

On health care financing and health insurance: draft law. № 2192 (2006). Retrieved from [Link]

On health care financing and health insurance: draft law. № 3370. (2003). Retrieved from [Link

On health care financing and health insurance: draft law. № 4279. (2009a). Retrieved [Link]

On Insurance, № 85/96-VR (1996). Retrieved from [Link]

Zhyrii, K. (2020). The National Bank announced a new law on insurance. Retrieved from [Link]

Shupa, L. Z. (2018). Implementation of Estonian medical insurance experience in Ukraine. Economic Analysis, 28(1), 168-171. Retrieved from [Link]

Вадим Александров, к.т.н., доцент, Сумський державний університет, (Україна);

Павло Рубанов, д.е.н., доцент, Сумський державний університет, (Україна),

Маді Мажед Ейса, Ph.D., Європейська асоціація урології (Німеччина).

Проблеми впровадження обов'язкового медичного страхування в Україні

Стаття присвячена питанням фрінансування галузі охорони здоров'я завдяки впровадженню обов'язкового та удосконалення добровільного медичного страхування в Україні. Основною метою дослідження $є$ теоретичне обгрунтування, а також визначення основних напрямків і рекомендацій щодо впровадження системи обов'язкового медичного страхування в Україні та пошуку можливих шляхів удосконалення медичного страхування в иілому. Систематизація літературних джерел та підходів до вирішення проблеми впровадження обов'язкового медичного страхування засвідчила, що громадяни України фактично не можуть безоплатно отримувати медичну допомогу в державних і комунальних закладах охорони здоров'я в обсязі та із якістю, гарантованими Конституцією України, а отже, їхнє конституційне право на охорону здоров'я і медичну допомогу не повною мірою реалізується. Актуальність вирішення цієї проблеми полягає в тому, що постає завдання щодо проведення комплексної рефоори всього механізму охорони здоров'я (особливо проблем фрінансування), включаючи його один із основних елементів - обов'язкового медичного страхування. Дослідження питання впровадження обов'язкового медичного страхування в Україні в статті здійснено в такій логічній послідовності: аналіз моделей, історичного досвіду та змішаної бюджетно-страхової системи фінансування охорони здоров'я; виявлення особливостей медичного страхування в Україні в умовах пандемії у 2020 році; з'ясування проблем розвитку медичного страхування в Україні та в світі; аналіз та розгляд теоретичних основ вирішення проблем медичного страхування; ретроспективний аналіз трирівневої моделі страхування; розроблення практичних рекомендацій щодо удосконалення механізмів упровадження обов'язкового медичного страхування. 
Методичним інструментарієм проведеного дослідження стали методи діалектичного наукового пізнання, системного підходу, статистичного та порівняльного аналізу, дослідження літературних джерел, нормативно-правової бази та звітів страхових компаній. Періодом дослідження обрано 2002-2021 рр. Це період, у якому до Верховної Ради України було подано 18 проєктів про загальнообов'язкове медичне страхування, і всі вони були відкликані або відхилені. Об'єктом дослідження обрана система медичного страхування та державні механізми регулювання обов'язкового та добровільного медичного страхування в Україні, оскільки саме вони, як показує аналіз закордонного досвіду, вирішують проблему додаткового фрінансування галузі охорони здоров'я й досягнення високої якості медичних послуг. У статті представлено результати емпіричного аналізу моделей, історичного досвіду та змішаної бюджетно-страхової системи фінансування охорони здоров'я, який засвідчив, що впровадження обов'язкового медичного страхування в Україні сприяє вирішенню питань доступності медичних послуг для широких верств населення і залученню додаткових ресурсів у сферу охорони здоров'я. Дослідження емпірично підтверджує та теоретично доводить, що при обов'язковому медичному страхуванні уряд України повинен: визначати перелік основних видів медичної допомоги, що надається і суму страхового внеску, який солідарно вносить держава, страхувальник та роботодавець; координувати взаємодію всіх учасників системи; вирішувати конфліктні ситуації; забезпечувати правові основи функціонування даної системи; контролювати фінансові потоки та діяльність страхового фонду. Результати проведеного дослідження можуть бути корисними для фахівиів страхового ринку, фінансово-економічним працівникам галузі охорони здоров'я, викладачам та студентам економічних спеціальностей.

Ключові слова: страхова медицина, обов'язкове медичне страхування, добровільне медичне страхування, страхові фонди, моделі медичного страхування, фінансування, охорона здоров'я. 